\section{OCCURRENCE OF MYCORRHIZA IN SAHELIYON KI BARI GARDEN UDAIPUR RAJASTHAN}

\author{
NITU PANWAR ${ }^{\mathrm{a} 1}$ AND PRAVINA RATHORE ${ }^{\mathrm{b}}$ \\ ${ }^{a b}$ Department of Botany, BN University, Udaipur, Rajasthan, India
}

\begin{abstract}
A study was conducted to identify mycorrhizal fungi present in soil of Saheliyon ki bari Garden, Udaipur, Rajasthan. It is a main tourist destination and presents a gorgeous view of greenery. The garden is famous for its green lawns, marble art and fountains. A total 14 number of species were recorded, which consisted of 8 species of genus Glomus, 2 species of Sclerocystis, 1 species each of Scutellospora, Entrophospora, Acaulospora \& Gigaspora. The highest number of species was recorded for the genus Glomus.
\end{abstract}

KEYWORDS: Mycorrhiza, Mycorrhizal Associations, Saheliyon Ki Bari Garden, Glomalin

Mycorrhiza literally translates to "fungus-root". Mycorrhiza is a mutually beneficial relationship between the root of a plant and a fungus, where the fungus facilitates water and nutrient uptake in the plant, and inturn the plant provides food and nutrients created by photosynthesis to the fungus. (Mycorrhizae) Mycorrhiza is a potential biofertilizer which mobilizes $\mathrm{P}, \mathrm{Fe}, \mathrm{Zn}$ and other trace elements to the plants.(Types of biofertilizer)

Mycorrhizal mycelia are much finer and smaller than roots and roots hairs, so they increase the surface area for absorption of water, phosphorus, amino acids and nitrogen. Mycorrhizal associations are beneficial in areas where the soil does not contain sufficient nitrogen and phosphorus, as well as in areas where water is not easily accessible. It is almost like a second set of roots. Mycorrhizal associations are more resistant to certain soil borne disease. (Mycorrhizae) The use of mycorrhizal fungi provides an effective method of disease control particularly in soil borne diseases. (Mukerji and Ciancio, 2007) It facilitates the phosphorus nutrition by not only increasing its availability, but also increasing its mobility. It can connect individual plants within a mycorrhizal network. This network functions to transport materials such as water and other nutrients from plant to plant. (Mycorrhizae)

Studies show that mycorrhizal association has improved plant growth in sunflower (Ibrahim, 2019), soyabean (Samanhudi et al., 2018), ornamental plants (Piischel et al., 2014) and Acacia nilotica (Rajendra and Jayasree, 2007).

Maintenance of soil structure is of critical importance to the preservation of soil functions and fertility. Mycorrhizal fungi play a major role in soil aggregation through hyphae networking (Mycorrhizal inoculant), secrete molecules like glycoprotein known as 'Glomalin' which has a cementing capacity to maintain soil particles together (Wright and Upadhyaya, 1996), increase soil porosity and promote aeration and water movement into the soil. (Mycorrhizal inoculant) Glomalin is operationally identified as glomalin-related soil protein (GRSP). It contributes to the formation of stable soil aggregates (Borie et al., 2008). Increased soil aggregates stability may protect adsorbed nutrients within soil aggregates (Emran et al., 2012). Arbuscular mycorrhizal fungi appear to be the only producers of glomalin which has the potential to increase soil carbon (C) and nitrogen $(\mathrm{N})$ storage and is mainly involved in soil aggregation.(Prasad et al., 2018) Therefore, their presence in the soil is significance to maintain physical soil properties.(Mycorrhizal inoculant)

Thus the present study was conducted to find the presence of mycorrhiza in garden soil.

\section{MATERIALS AND METHODS}

\section{Sampling Site Description}

Udaipur is the beautiful city of the state of Rajasthan, India. The city is lush green and offers a lot of place to visit. Udaipur has many gardens and parks. (Gardens and parks in Udaipur, 2018) Among the beautiful gardens, Saheliyon ki bari garden was selected for the present research work. Saheliyon Ki Bari means "Garden of maids". This garden is located on the banks of Fateh Sagar Lake. It was built by Maharana Sangram Singh for the royal ladies in the 18th century. The garden

${ }^{1}$ Corresponding author 
is embellished with numerous fountains in its four water pools, chiseled kiosks and marble elephants. It is also eminent for its lotus pool and bird fountains. The lush green lawns, flowerbeds and marble pavilions further enhance the romantic ambience of this magnificent garden.(Saheliyon ki bari)

Vegetationally garden is rich in angiospermic plants which includes Livistona chinensis (fan palm), Roystonea regia (royal palm), Ixora coccinea (jungle flame), Gardenia jasminoides (cape jasmine), Hamelia patens (fire bush), Hibiscus rosa cinencis (china rose), Nirium, Gerbera, Hymenocallis, Rose etc.

\section{Collection of Samples}

Soil samples were collected randomly from the rhizosphere of plants growing in this garden. Soil sample were collected in july-august (rainy season). Soil samples were collected at 2 different depth $0-10 \mathrm{~cm}$. and 10-20 $\mathrm{cm}$. The collected soil samples were taken in sealed plastic bags, labelled and transported to the laboratory. Before processing, all the soil samples were sieved (through $<2 \mathrm{~mm}$ sieve) to remove stones, coarse roots and other litter. Soil samples were air dried and stored for further experiments. (Pal and Pandey, 2014)

\section{Isolation of Spores}

Spores of mycorrhizal fungi were isolated from soil samples by using the wet sieving and decanting method described by Gerdemann and Nicolson, 1963. (Gerdermann and Nicolson, 1963) Spores were examined under microscope and photographs were taken.

\section{Identification of Spores}

Spore identification was based mainly on spore size and colour, wall structure and hyphal attachment. For more accuracy, photographs were sent to Dr. J.C. Tarafdar, Former Principal Scientist from Jodhpur for identification.

\section{RESULTS}

Based on spore size and colour, wall structure and hyphal attachment following species were recorded (Table 1)

Following photographs were taken from isolated mycorrhizal spores.
Table 1:

\begin{tabular}{|c|c|c|}
\hline S.No. & Name of genus & Name of Species \\
\hline 1 & Glomus & Fasciculatum \\
\hline 2 & Glomus & Tenerum \\
\hline 3 & Glomus & Mosseae \\
\hline 4 & Glomus & Citricolum \\
\hline 5 & Glomus & Invermaium \\
\hline 6 & Glomus & Pulvinatum \\
\hline 7 & Glomus & Pansihales \\
\hline 8 & Glomus & Geosporum \\
\hline 9 & Sclerocystis & Sinuosa \\
\hline 10 & Sclerocystis & Pakistanica \\
\hline 11 & Acaulospora & Rugosa \\
\hline 12 & Gigaspora & Albida \\
\hline 13 & Entrophospora & Infrequens \\
\hline 14 & Scutellospora & Bionarta \\
\hline
\end{tabular}

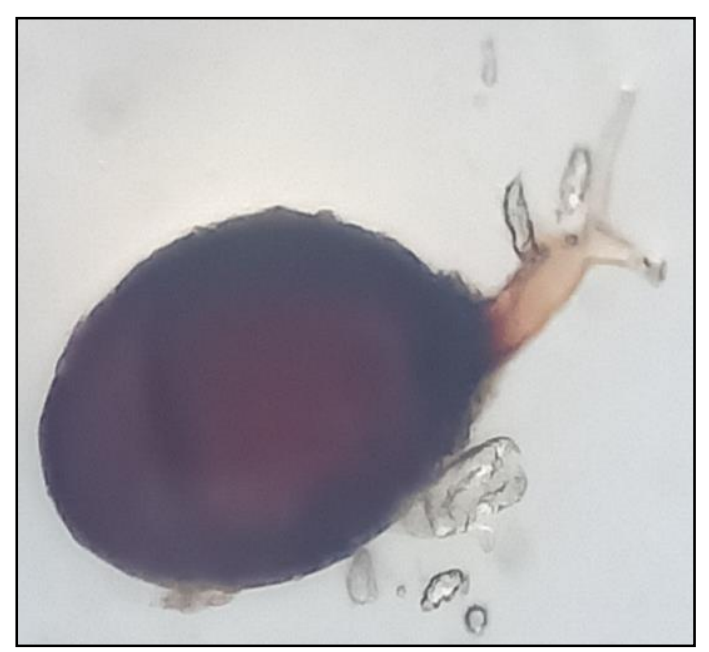

Figure 1: Glomus invermaium

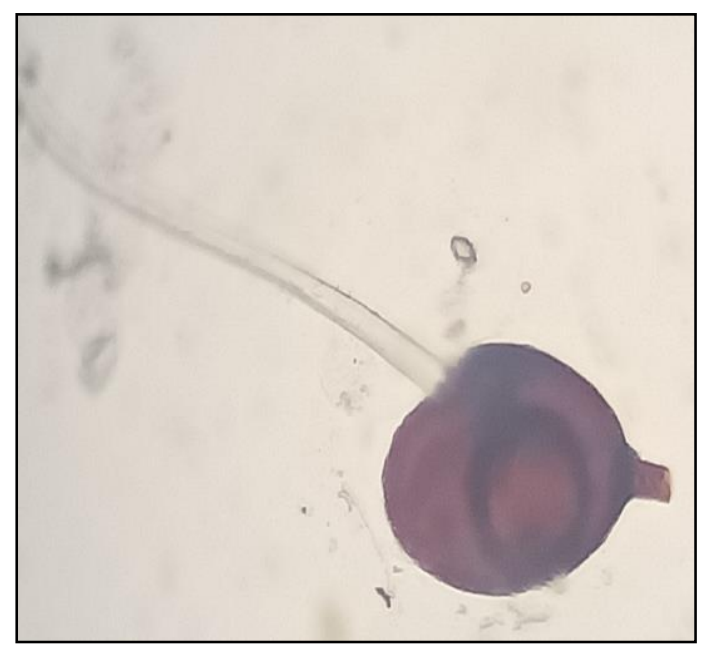

Figure 2: Entrophospora infrequens 


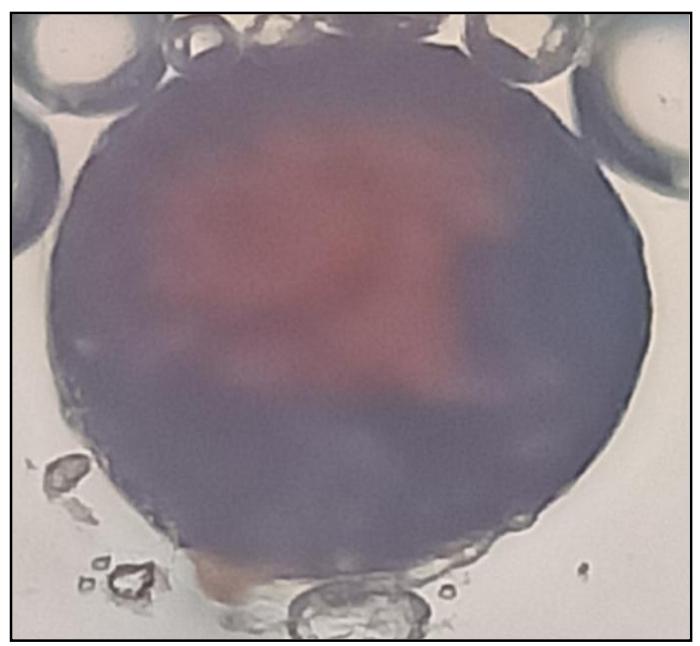

Figure 3: Glomus fasciculatum

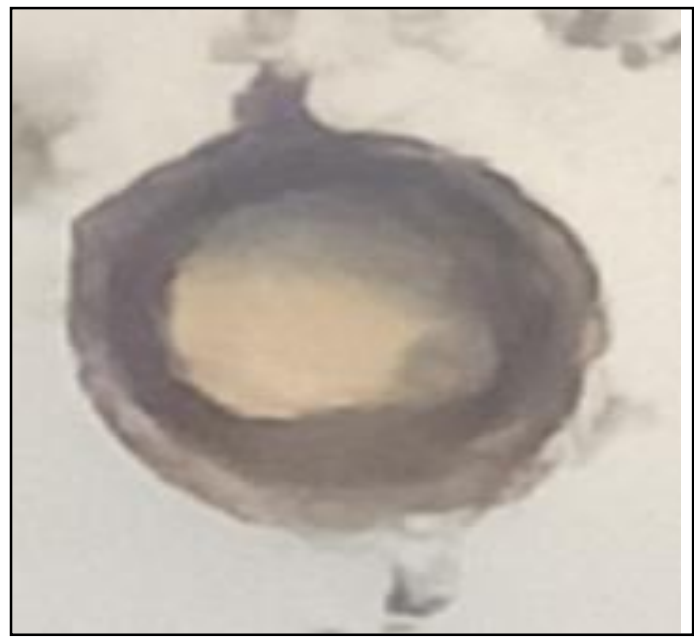

Figure 4: Acaulospora -rugosa

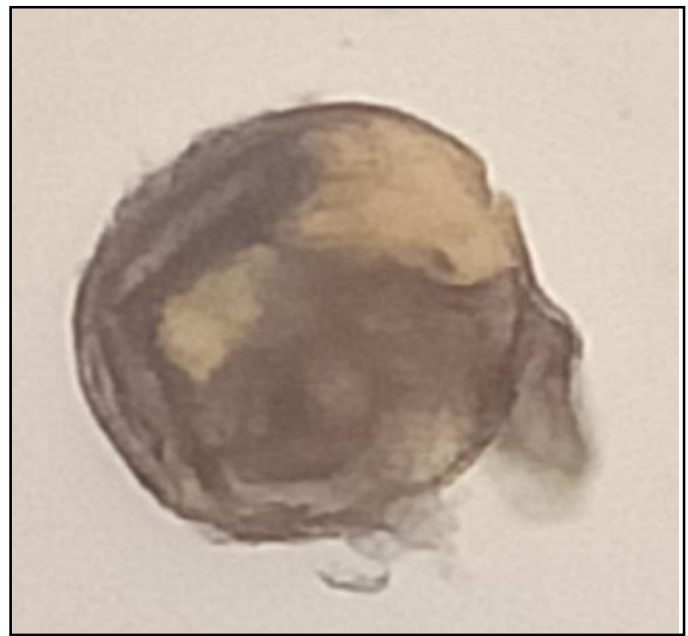

Figure 5: Gigaspora albida (Dried spore)

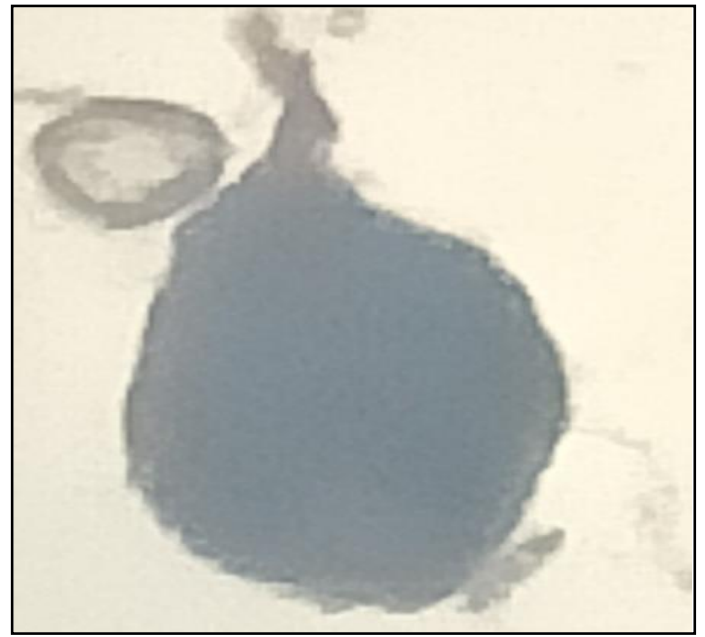

Figure 6: Sclerocystis sinuosa

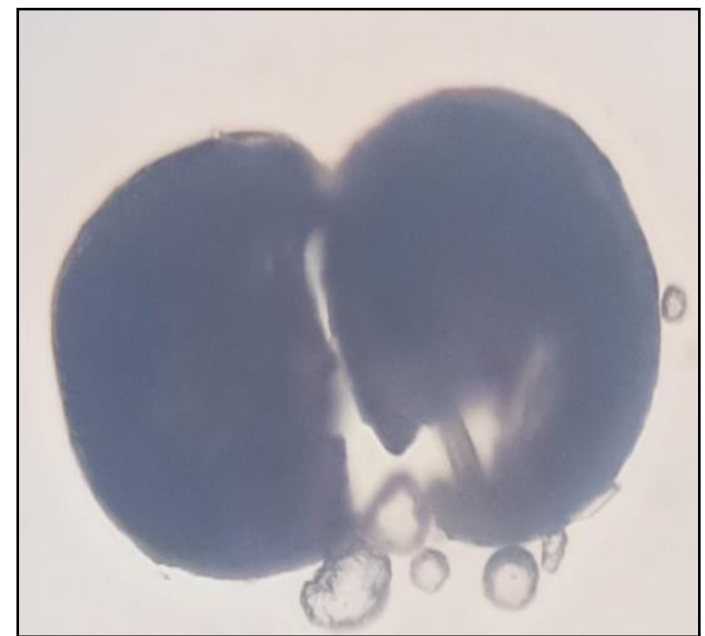

Figure 7: Scutellospora bionarta

\section{DISCUSSION}

The study showed a wide occurrence of mycorrhiza in the soil. A total 14 species and 6 genera of mycorrhizal fungi were recorded. The richness of mycorrhiza in the soil is an indication of its high fertility from earlier times. Looking at the commercial value of the greenery in the garden, its maintenance is of utmost importance and mycorrhiza may be of great help to this. The study is a first report of the presence of mycorrhizal fungi in a garden soil of Udaipur. Further investigation of soil properties and mycorrhizal association is carried on to explore the application of mycorrhizal fertilizer in this and other gardens.

\section{ACKNOWLEDGEMENT}

We are thankful to Dr. Renu Rathore, Dean faculty of science and Dr.Mohan Singh Rathore, Head Department of Botany, Bhupal Nobels, University, Udaipur, for providing needed amenities to complete our 
research work and also very thankful to Dr. J.C. Tarafdar, Jodhpur, for identification of mycorrhizal species.

\section{REFERENCES}

Borie F., Rubio R. and Morales A., 2008. "Arbuscular mycorrhizal fungi and soil aggregation". Journal of Soil Science and Plant Nutrition, 8: 9-18.

Emran M., Gispert M. and Pardini G., 2012. "Patterns of soil organic carbon, glomalin and structural stability in abandoned Mediterranean terraced lands". European Journal of Soil Science, 63: 637-649.

Gardens and parks in Udaipur information from http://www.Udaipur.org.uk/gardens/Saheliyonki-bari.html

Gerdermann J.W. and Nicolson T.H., 1963. "Spores of mycorrhizal Endogone species extracted from soil by wet sieving and decanting". Trans. Brit. Mycol. Soc., 46: 235-244.

Ibrahim M., 2019. "Sunflower response to inoculation with single and mixed species of Arbuscular mycorrhizal fungi: Agronomic Characteristics". Acta agriculturae Slovenia, 113(2).

Mycorrhizae information from https://www.biolog dictionary.net/mycorrhizae

Mycorrihizal inoculants information from http://www.my kepro.com/mycorrhizae-benefits-applicationand-research.aspx

Mukerji K.G. and Ciancio A., 2007. "Mycorrhizae in the integrated pest and disease management". Springer, pp.245-266.
Pal A. and Pandey S., 2014. "Methods to Process Isolation of VAM/AM Fungi in Vascular Plants Roots and Rhizosphere Soil in Jaipur District(Raj.), India”. International Journal of scientific research, 2(9): 127-129.

Piischel D., Rydlova J. and Vosatka M., 2014. "Can mycorrhizal inoculation stimulate the growth and flowering of peat-grown ornamental plants under standerd or reduced watering?". Applied soil ecology, 80: 93-99.

Prasad M., Chaudhary M., Srinivasan R. and Mahawer S.K., 2018. "Glomalin: A miracle protein for soil sustainability”. Indian Farmer, 5(09): 10921100 .

Rajendran K. and Jayasree R., 2007. "Effect of Biofertilizers on quality seedling production of Acacia nilotica". Journal of Non-timber products, 14: 5-11.

Saheliyon ki bari information from https://udaipur blog.com/gardens-and-parks-in-udaipur.html

Samanhudi, Pujiasmanto B., Sudadi Putra I.H. and Mumtazah H.M., 2018. "The efficiency of mycorrhiza biofertilizer treatment to tha growth and yield of soybean". Earth and environmental science, 142: 1-7.

Types of biofertilizer information from https://www.biofit-eu/q8/lo1-why-biofertilizer?Start=4

Wright S.F. and Upadhyaya A., 1996. "Extraction of an abundant and unusual protein from soil and comparison with hyphal protein from arbuscular mycorrhizal fungi”. Soil Science, 161(9): 575586. 